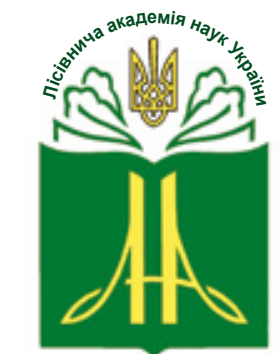

Forestry Academy of Sciences of Ukraine
Наукові праці Лісівничої академії наук України Proceedings of the Forestry Academy of Sciences of Ukraine

\author{
http://fasu.nltu.edu.ua \\ https://doi.org/10.15421/411929 \\ Article received 2019.05.28 \\ Article accepted 2019.12.26
}

\author{
ISSN 1991-606X print \\ ISSN 2616-5015 online \\ (a) $\triangle$ Correspondence author \\ Yuriy Shparyk \\ yuriy.shparyk@gmail.com \\ Hrushevsky str., 31, Ivano-Frankivsk, 76018, Ukraine
}

\title{
Прогноз всихання ялинників в Українських Карпатах за типами лісу
}

\author{
Ю.С. Шпарик ${ }^{1}$
}

\begin{abstract}
Масове всихання ялинових лісів Українських Карпат в останнє десятиріччя вже у найближчому майбутньому зумовить дефіциит ялинової деревини, яка зараз є майже безальтернативною для різних галузей промисловості. Тому, актуальним є прогнозування площі та запасів ялини як з наукових позицій, так $і$ для підприємств лісового господарства. Одним із найефективніших методів прогнозування є екстраполяція існуючих тендениій, наприклад, всихання ялини, на перспективу. Закономірності всихання ялинників регіону були ідентифіковані на більи як 20 постійних дослідних об'єктах УкрНДІгірліс у 2010-2019 роках. Аналіз отриманих результатів дав змогу оиінити інтенсивність всихання ялинників за такими складовими: тип лісу, група віку, група повноти та частка ялини у породному складі.

Встановлено, щуо в умовах вологої чистої сусмеречини середня інтенсивність всихання (втрати запасу ялинової деревини) середньовікових і середньоповнотних лісів з часткою ялини у породному складі на рівні 6-7 одиниць склала 3, для вологої буково-ялицевої сусмеречини - 1, а для вологої буково-смерекової суяличини - $2 \%$ за рік. Виявлені тенденції всихання дали можливість підготувати схему розрахунку площі та запасу ялини на наступні 20 років. Прогнозування до 2040 р. дало такі результати: середні втрати площзі ялинників у смерекових типах лісу складуть 28, в букових - 63, в ялицевих - 53\%; середні втрати запасу ялинової деревини у смерекових типах лісу складуть 80, в букових - 92, в ялицевих - 80\%. Сумарно в державних підприємствах лісового господарства Українських Карпат наслідком всихання стане зменшення площі ялинників з 425,6 до 328, 9 тис. га, а

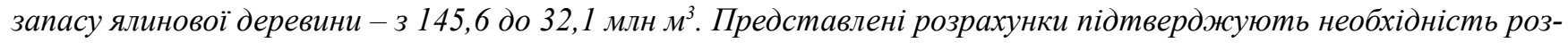
робки регіональної програми з відновлення ялинових лісів в Українських Карпатах.
\end{abstract}

Ключові слова: площа ялинників; запас ялинової деревини; інтенсивність всихання; лісорослинні умови; групи віку; повнота; склад деревостану; екстраполяція; державні підприємства лісового господарства.

Вступ. Багаторічні дослідження санітарного стану ялинових лісів Українських Карпат свідчать про наявність різнобічних проблем зі всиханням ялини в регіоні: швидкий ріст ялинників призводить до наявності в цих деревостанах мертвої деревини (відпаду), яка дає високий інфекційний фон і викликає потребу в проведенні заходів з поліпшення санітарного стану ялинників; коренева система смереки розташована у верхніх шарах грунту і за низької вологості повітря і відсутності постійних опадів втрачає свою функціональність; розширення осередків Heterobasidion annosum (Fr.) Bref. знижує стійкість ялинників; інтенсивне зростання чисельності Ips typographus L. за наявності сухостою прискорює всихання ослаблених дерев ялини; похідні ялинники в переважній більшості ростуть у не властивих для смереки лісорослинних умовах, що зумовлює їх розладнання та всихання в більш молодому віці, порівняно 3 корінними деревостанами (Vasechko, 1967, Golubets, 1978, Bigun, 1990,

Шпарик Юрій Степанович - член-кореспондент Лісівничої академії наук України, доктор сільськогосподарських наук, головний науковий співробітник. Український науково-дослідний інститут гірського лісівництва імені П.С. Пастернака, вул. Грушевського, 31 , м. Івано-Франківськ, 76018, Україна. Тел.: 0342-53-02-36, +38-050-188-02-61. E-mail: yuriy.shparyk@gmail.com ORCID: https://orcid. org/0000-0001-8047-6356 
Trybun, 1996, Slobodyan, 2000, Debryniuk, 2011, Shparyk, 2013, Kramarets, 2018). А оскільки ці проблеми залежать від типів лісу, то прогноз всихання ялинників має базуватися саме на особливостях їхнього росту і розвитку, тобто - на результатах моніторингу дослідних об'єктів за типами лісу.

Всихання ялинників Українських Карпат в останні роки має поширення в усіх типах лісу, де росте ялина, а за охопленою площею (від 20 до 50 тис. га в рік) набуло характеру катастрофічного явища 3 антропогенних і природних причин. При цьому, масове всихання ялинників має місце не залежно від способів господарювання і типів деревостану. Під наметом більшості ялинників, що всихають, відмічено успішне природне поновлення, в якому не завжди переважає підріст ялини - частіше бук та ялиця (Fenton, Simard, \& Bergeron, 2009, Mauer \& Palátová, 2010, Janda et al., 2014, Debryniuk, 2014, Shparyk, 2014, Šebeň, Konôpka, Bošel'a1, \& Pajtík, 2015 , FAO, 2016). Основним наслідком інтенсивного всихання ялини є зміна породного складу та головної породи в ялинниках Українських Карпат місце Picea abies (L.) Karst. в деревостанах природним шляхом займає переважно Fagus sylvatica L., хоча в дубових типах лісу це може бути Carpinus betulus L., Tilia cordata Mill. чи клени, а в ялицевих - Abies alba Mill. Тобто, в лісівничому плані загрози втрати площі лісового фонду немає, хоча зрозуміло, що цінність ялинових та букових лісів для промислового використання різна. Розрахунок економічних (коротко- і довготермінових), екологічних (біорізноманіття, депонування вуглецю, продукування кисню) та соціальних (зайнятість місцевого населення, рекреаційна ємність) наслідків всихання ялинників регіону дає підстави говорити про наявність як негативних, так і позитивних аспектів у цьому процесі, і вони мають суттєві відмінності у різних типах лісу (Kirschbaum, 2004, Dunn et al., 2006, Feltona, Lindbladh, Bruneta, J., \& Fritz, 2010, UkrRIMF, 2014, Shparyk, 2017, 2019a).

При цьому ялинова деревина є основним круглим лісоматеріалом регіону, який використовують для виготовлення різноманітних пиломатеріалів. Так, за даними сортиментації деревини від рубок головного користування в 2020 р., вихід круглих лісоматеріалів у ялини майже в два рази більший, ніж у бука (75 проти $40 \%$ ), а з урахуванням якості пиломатеріалів та їх ціни, про повноцінну заміну ялинових лісоматеріалів буковими говорити не доцільно. А незначні запаси ялицевої та модринової деревини в регіоні дають підставу говорити про винятково важливе економічне значення ялинової деревини для лісових та деревообробних підприємств Українських Карпат (SAFRU, 2019). Тому, прогнозування площі ялинників, які залишаться рости в перспективі, і особливо - запасів ялинової деревини в них, $\epsilon$ актуальним для зміни пріоритетів у наукових дослідженнях і зміни лісівничих заходів у напрямі збереження ялини, а також для переорієнтації лісогосподарських підприємств на вирощування інших типів деревостанів.
Об'єкти та методика досліджень. Оскільки прогнозування - це оцінка (розрахунок) майбутнього стану предмету прогнозування на основі аналізу його попередньої динаміки (Bergha, 1998, Lavryk, 2010, Bokoch, Lakyda, Vasylyshyn, Terentjev, 2012, Lakyda \& Blyschyk, 2014, Kansanen, Vauhkonen, Lähivaara, \& Mehtätalo, 2016), то для розрахунків змін в ялинниках Українських Карпат у найближчі роки використано інформацію про їх динаміку на постійних дослідних об' єктах за типами лісу. Об 'єкти досліджень зосереджені більш як на 20-ти постійних пробних площах УкрНДІгірліс за участю смереки в основних типах лісу. Їхній лісівничо-таксаційних опис детально представлений в попередніх публікаціях (Shparyk, 2014, 2017, UkrRIMF, 2014). Предмет дослідження - інтенсивність змін запасів ялинової деревини та ії̈ частки в породному складі деревостанів в ялинниках регіону, які всихають, за типами лісу. Мета досліджень - дати прогноз площі ялинників та запасу ялинової деревини в Українських Карпатах за типами лісу на найближчі 20 років.

Інтенсивність всихання ялинників визначали на дослідних об'єктах у відсотках зменшення запасу деревини за роками. Для прогнозування змін санітарного стану ялинників прийнято базове положення, яке $\epsilon$ результатом здійснених досліджень - інтенсивність всихання ялинників визначається трьома показниками в межах одного типу лісу: групою віку ялинових насаджень, повнотою деревостану, часткою ялини у породному складі. Для розрахунку прогнозних значень змін ялинових лісів використано функцію екстраполяції існуючих тенденцій цих змін. Великою перевагою такого методу є те, що існуючі закономірності в динаміці лісів мають місце на конкретних дослідних об'єктах і властиві саме для цих типів лісу.

Також як базове прийнято припущення, що кліматичні показники останніх років будуть мати сталі тенденції. Достовірні результати інтенсивності всихання ялинників були визначені лише для тих типів лісу, в яких було не менше трьох дослідних об'єктів - в умовах вологої чистої сусмеречини, вологої буково-ялицевої сусмеречини, вологої буково-смерекової суяличини. Для екстраполяції інтенсивності всихання ялинників на інші (не представлені на дослідних об'єктах) типи лісу використано наступні встановлені закономірності: за збільшення вологості типів лісу інтенсивність всихання ялини зменшується, а за зменшення вологості збільшується; за збільшення трофності типів лісу інтенсивність всихання ялини зменшується, а за зменшення - збільшується; в мішаних лісостанах інтенсивність всихання ялини менша, ніж у чистих; в не смерекових типах лісу інтенсивність всихання ялини більша, ніж у смерекових, а в типах лісу за межами природного ареалу ялини інтенсивність всихання ще вища.

Методичні критерії прогнозування санітарного стану всихаючих ялинників підібрані через оцінку достовірності розроблених на їх основі прогнозів. 
Її результатом стали наступні критерії прогнозування, які проранговані за впливом на інтенсивність всихання ялини: а) тип лісу визначає інтенсивність всихання, оскільки репрезентує лісорослинні умови та їх зміни за останні роки; б) група віку визначає певний рівень життєздатності ялинників, який зменшується з віком; в) повнота деревостану визначає мікроклімат у насадженні, який стає сухішим у випадку його розрідженння (зменшення повноти); г) частка ялини в породному складі впливає на ін-

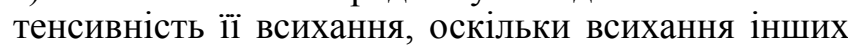
порід не таке суттєве.

Назви типів лісу, наведені у лісовпорядкувальних матеріалах, в окремих випадках нами уточнені згідно «Діагностичної характеристики типів лісу Українських Карпат» (Gerushinskyy, 1996).

Макет прогнозу (електронну таблицю) всихання ялини розроблено у середовищі MS Excel. Для розрахунку використано розподіл площі ялинників та запасу деревини ялини за критеріями прогнозування (типи лісу, групи віку, групи повноти, частка ялини в породному складі) з реляційної бази даних лісовпорядкування станом на 2019 р. для лісового фонду підприємств Державного агентства лісових ресурсів України (ДАЛРУ) в регіоні Українських Карпат. За подібністю інтенсивності всихання ялинові деревостани були згруповані в три групи повноти (менше 0,$40 ; 0,41-0,80 ; 0,81$ і вище) i прогноз зроблено для кожної групи окремо. Приклад розрахунку змін запасу ялинників 3 відносною повнотою $0,41-0,80$ в умовах вологої буковоялицевої сусмеречини для всіх підприємств ДАЛРУ в регіоні за період 2019-2021 рр. наведено в табл. 1. Такий підхід дав змогу встановити, що за використання зазначених критеріїв прогнозування запас ялинової деревини в цьому типі лісу зменшився з 43,5 до 37,5 млн м³ , а площа - 3116,9 до 114,1 тис. га. Подібні таблиці, однак на значно більший віковий період (2019-2040рp.), з прогнозами окремо для площі ялинників і окремо - для запасу ялинової деревини розроблені для всіх типів лісу регіону, де ростуть ялинники, і окремо для кожної з трьох груп повнот - всього опрацьовано більше 300 таких таблиць.

Таблиия 1

Прогноз запасів ялинової деревини у вологій буково-ялицевій сусмеречині на період 2019-2021 рр., тис. м ${ }^{3}$

\begin{tabular}{|c|c|c|c|c|c|c|}
\hline $\begin{array}{l}\text { Частка } \\
\text { ялини }\end{array}$ & $\begin{array}{l}\text { Молодняки } \\
1 \text { класу віку }\end{array}$ & $\begin{array}{l}\text { Молодняки } \\
2 \text { класу віку }\end{array}$ & $\begin{array}{c}\text { Середньо- } \\
\text { вікові }\end{array}$ & Пристигаючі & Стиглі & Перестійні \\
\hline 1 & 2 & 3 & 4 & 5 & 6 & 7 \\
\hline \multicolumn{7}{|c|}{2019 рік } \\
\hline 10 & 19,43 & 566,29 & 12446,50 & 3267,80 & 2444,57 & 148,64 \\
\hline 9 & 17,90 & 308,48 & 3852,77 & 1059,44 & 835,36 & 53,29 \\
\hline 8 & 36,21 & 399,39 & 3932,27 & 1251,83 & 1105,74 & 129,81 \\
\hline 7 & 61,31 & 300,23 & 2468,77 & 804,86 & 753,18 & 81,65 \\
\hline 6 & 78,64 & 259,06 & 1672,60 & 719,30 & 618,24 & 98,13 \\
\hline 5 & 49,89 & 150,56 & 1044,39 & 430,21 & 418,34 & 90,63 \\
\hline 4 & 23,14 & 81,59 & 486,75 & 367,59 & 231,08 & 73,59 \\
\hline 3 & 6,70 & 7,51 & 87,39 & 55,13 & 61,19 & 23,47 \\
\hline 2 & 2,16 & 0 & 2,66 & 0 & 1,24 & 0 \\
\hline 1 & 0 & 0 & 0 & 0 & 0 & 0 \\
\hline+ & 0 & 0 & 0 & 0 & 0 & 0 \\
\hline \multicolumn{7}{|c|}{2020 рік } \\
\hline 10 & 18,225 & 528,547 & 11503,065 & 2990,782 & 2215,826 & 133,448 \\
\hline 9 & 16,953 & 290,716 & 3595,303 & 979,043 & 764,545 & 48,308 \\
\hline 8 & 34,295 & 376,390 & 3669,490 & 1156,833 & 1012,004 & 117,674 \\
\hline 7 & 58,636 & 285,715 & 2326,377 & 751,074 & 696,090 & 74,742 \\
\hline 6 & 75,210 & 246,535 & 1576,128 & 671,232 & 571,378 & 89,828 \\
\hline 5 & 48,187 & 144,699 & 993,896 & 405,435 & 390,458 & 83,784 \\
\hline 4 & 22,350 & 78,414 & 463,217 & 346,422 & 215,679 & 68,031 \\
\hline 3 & 6,503 & 7,254 & 83,579 & 52,214 & 57,396 & 21,805 \\
\hline
\end{tabular}


Продовж. табл. 1

\begin{tabular}{ccccccc}
\hline 1 & 2 & 3 & 4 & 5 & 6 & 7 \\
\hline 2 & 2,097 & 0,000 & 2,544 & 0,000 & 1,163 & 0,000 \\
1 & 0,000 & 0,000 & 0,000 & 0,000 & 0,000 & 0,000 \\
+ & 0,000 & 0,000 & 0,000 & 0,000 & 0,000 & 0,000 \\
\hline \multicolumn{7}{c}{2021 рік } \\
\hline 10 & 17,095 & 493,320 & 10631,141 & 2737,247 & 2008,486 & 119,809 \\
9 & 16,056 & 273,974 & 3355,042 & 904,747 & 699,733 & 43,792 \\
8 & 32,480 & 354,715 & 3424,272 & 1069,045 & 926,214 & 106,673 \\
7 & 56,079 & 271,901 & 2192,197 & 700,882 & 643,326 & 68,419 \\
6 & 71,930 & 234,616 & 1485,221 & 626,376 & 528,068 & 82,229 \\
5 & 46,541 & 139,067 & 945,843 & 382,088 & 364,435 & 77,455 \\
4 & 21,587 & 75,362 & 440,821 & 326,472 & 201,304 & 62,892 \\
3 & 6,313 & 7,006 & 79,934 & 49,452 & 53,837 & 20,258 \\
2 & 2,035 & 0,000 & 2,433 & 0,000 & 1,091 & 0,000 \\
1 & 0,000 & 0,000 & 0,000 & 0,000 & 0,000 & 0,000 \\
+ & 0,000 & 0,000 & 0,000 & 0,000 & 0,000 & 0,000 \\
\hline
\end{tabular}

У схемі розрахунку враховано також наступні положення: всихання ялини призводить до зменшення запасів іiі деревини, а, значить, і до зменшення iї частки у породному складі; розрахункову лісосіку для головного користування прийнято «за стиглістю», тобто щорічно зрубується десята частина стиглих і перестійних ялинників; розрахункову лісосіку санітарних рубок прийнято «за станом», тобто щорічно зрубується сухостій ялинників; інші рубки здійснюють разом із санітарними в обсязі щорічного приросту; лісовідновлення збільшує площу ялинників після переведення зрубів у вкриті лісовою рослинністю ділянки (під час повторного лісовпорядкування).

Результати та обговорення. Достовірні результати інтенсивності всихання ялинників за типами лісу були визначені тільки для трьох типів лісу: вологої чистої сусмеречини - середня інтенсивність всихання склала $3 \%$ за рік; вологої буковоялицевої сусмеречини - всихання $1 \%$ за рік; вологої смереково-букової суяличини - всихання $2 \%$ за рік. Відмітимо, що саме в цих типах лісу площа ялинників у регіоні Українських Карпат найбільша. Встановлена на дослідних об'єктах частка всихання ялинових лісостанів характеризує середні значення всихання, а, саме, в середньовікових i середньоповнотних лісах 3 часткою ялини в породному складі на рівні 6-7 одиниць. На постійних дослідних об'єктах встановлено наступні тенденції всихання ялини: за групами віку інтенсивність всихання ялинників зменшується у випадку зменшення їхнього віку i, відповідно, збільшується у випадку збільшення віку; за часткою ялини у складі деревостану тенденція всихання ялинників подібна до такої за віком - інтенсивність всихання ялинників зменшується за зменшення частки ялини від 6-7 до 1-2 одиниць і відповідно збільшується - за збільшенні їі частки до 9-10 одиниць; за повнотою деревостанів інтенсивність всихання збільшується за зменшення повноти від 0,6-0,7 до 0,1-0,2 і зменшується за збільшення повноти до 1,0 ; однак, за подальшого збільшення повноти інтенсивність всихання перегущених (повнота більше 1,0 ) ялинників знову починає зростати. Отримані результати дали можливість встановити інтенсивність всихання ялинових деревостанів за типами лісу (Shparyk, 2019b).

Оскільки найбільші площі ялинників зосереджені саме у смерекових типах лісу регіону, то аналіз результатів прогнозу щодо всихання смереки розпочнемо з них. Динаміка площі ялинників у смерекових типах лісу має певні відмінності (рис. 1). Якщо в умовах вологого кедрово-смерекового бору площа ялинників зменшилася на $66 \%$, то для вологого смерекового субору це зменшення склало 35 , для вологої чистої сусмеречини - 18 , а для вологої буково-ялицевої смеречини - лише $3 \%$. Такі значні відмінності в інтенсивності всихання ялинників (від 3 до 66\%) значною мірою пояснюються їхнім розподілом за критеріями прогнозування, тому що навіть у близьких за лісорослинними умовами типах лісу інтенсивність всихання ялини дуже різниться: від $49 \%$ в умовах вологого кедровосмерекового бору, $35 \%$ - для вологого смерекового субору, $18 \%$ - в умовах вологої чистої сусмеречини до $10 \%$ - для вологої буково-ялицевої сусмеречини (за даними лісовпорядкування площа лісів в останньому типі лісу перевищує 20 тис. га). Відзначимо, 
що прогноз дає навіть незначне збільшення площ ялинників в 2030 і 2040 роках (проте не для всіх типів лісу), що пояснюється переведенням не вкритих у вкриті лісовою рослинністю ділянки під час лісовпорядкування (на місці ялинників, які всохли, знову формуються ялинові молодняки).

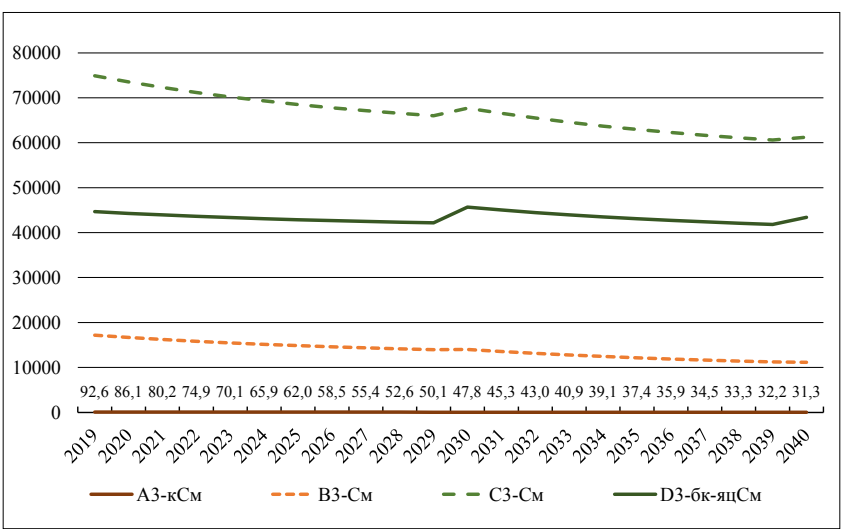

Рис. 1. Динаміка площі (га) ялинників у смерекових типах лісу (цифрами вказано прогнозовану динаміку площі ялинників в умовах $A_{3}-\kappa C M$ )

Динаміка запасу деревини ялинників у смерекових типах лісу теж відрізняється, однак швидкість зменшення запасів значно вища в межах окремого типу лісу, ніж зменшення площі ялинників для цих же типів лісу (рис. 2). Так, в умовах вологого кедрово-смерекового бору запас деревини ялинників зменшиться прогнозовано на $95 \%$ (площа лише на $66 \%$ ). Для вологого смерекового субору це зменшення складе 89 , для вологої чистої сусмеречини -88 , а для вологої буково-ялицевої смеречини $-48 \%$. Таким чином, втрати ялинової деревини в смерекових типах лісу Українських Карпат у найближчі 20 років прогнозуються в межах 48-95\% від існуючого запасу, за середнього значення $81 \%$.

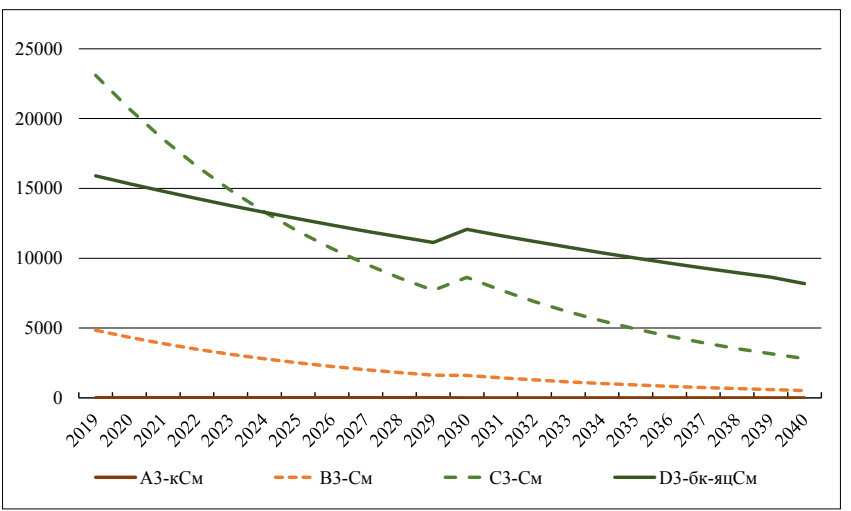

Рис. 2. Динаміка запасу деревини (тис. м³) ялинників у смерекових типах лісу

Площа ялинників у букових типах лісу, порівняно зі смерековими, змінюється не так різко (рис. 3). Про це свідчить менший розмах значень інтенсивності всихання ялинників - від мінімуму $(55 \%)$ в умовах вологої чистої бучини до максимуму $(73 \%)$ - в умовах вологої яворової субучини (на жаль, значна кількість букових типів лісу не дає змоги представити всіх їх на графіку). Для найпоширеніших букових типів лісу цей діапазон ще менший: в умовах вологої чистої субучини площа ялинників зменшилася на $65 \%$; для вологої смереково-ялицевої субучини це зменшення склало теж $65 \%$; для вологої чистої бучини - 73; для вологої смереково-ялицевої бучини - $62 \%$.

Запас деревини ялинників у букових типах лісу, порівняно зі смерековими, змінюється досить плавно, а швидкість зменшення запасів значно вища, ніж зменшення площі ялинників у конкретному типі лісу (рис. 4).

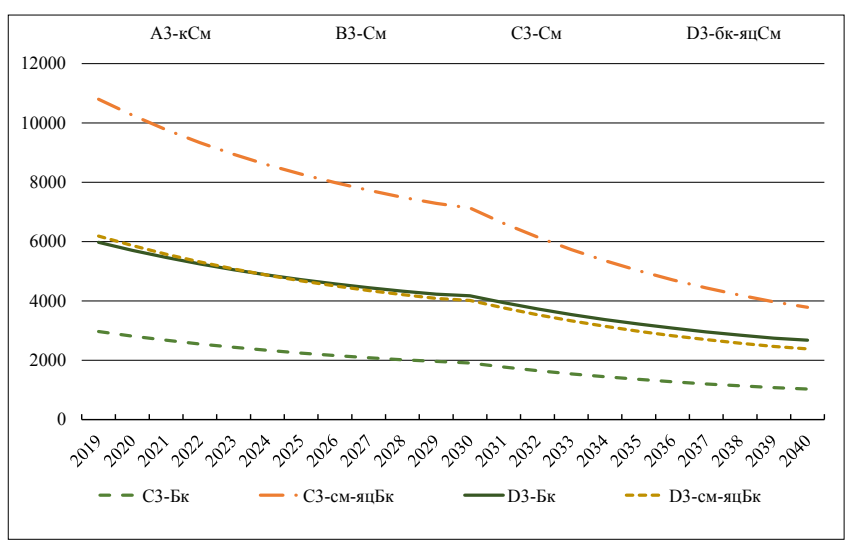

Рис. 3. Динаміка площі (га) ялинників у букових типах лісу

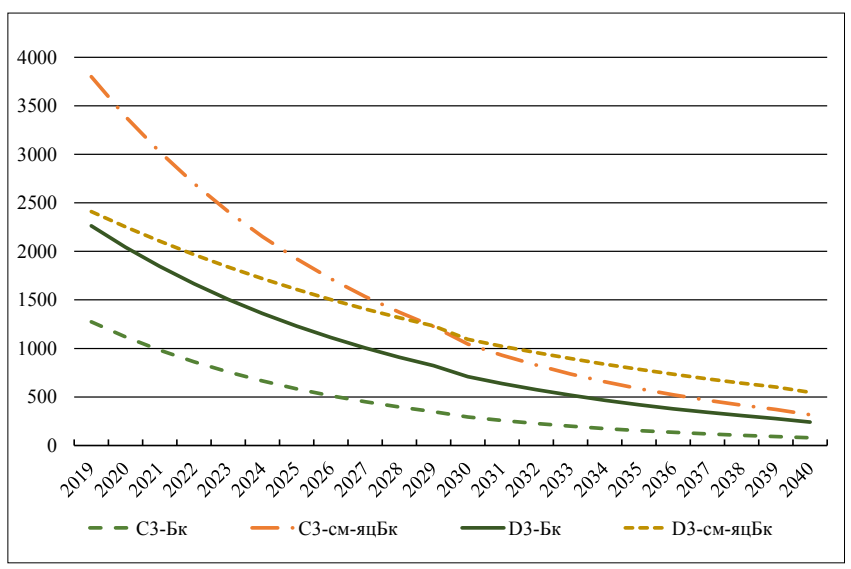

Рис. 4. Динаміка запасу деревини (тис. м $^{3}$ ) ялинників у букових типах лісу

Так, в умовах вологої чистої субучини запас стовбурової деревини ялинників прогнозовано зменшиться на $94 \%$ (площа - на $65 \%$ ), для вологої смереково-ялицевої субучини це зменшення склало 92 , для вологої чистої бучини - 89, а для вологої смереково-ялицевої бучини - $77 \%$. Тобто, втрати ялинової деревини в букових типах лісу Українських Карпат у найближчі 20 років прогнозуються в межах 77-97\% від існуючого запасу за середнього значення в $92 \%$, що на $10 \%$ більше, ніж у смерекових типах лісу.

Динаміка площі ялинників в ялицевих типах лісу значною мірою подібна до такої у букових типах (рис. 5). Такий самий незначний розмах зна- 
чень інтенсивності всихання ялинників - від 55\% в умовах вологої ялицевої судіброви (за реляційною базою даних лісовпорядкування станом на 1.01.2019 р. площа лісів в цьому типі лісу перевищує 1 тис. га) до $59 \%$ в умовах вологої смерековобукової суяличини значною мірою пояснюється подібними їх лісорослинними умовами та подібністю критеріїв прогнозування. Для найпоширеніших ялицевих типів лісу коливання за інтенсивністю всихання ялини склали: в умовах вологої ялицевої судіброви площа ялинників зменшилася на $55 \%$; у вологій смереково-буковій суяличині - на $59 \%$; у вологій смереково-буковій яличині - на $56 \%$.

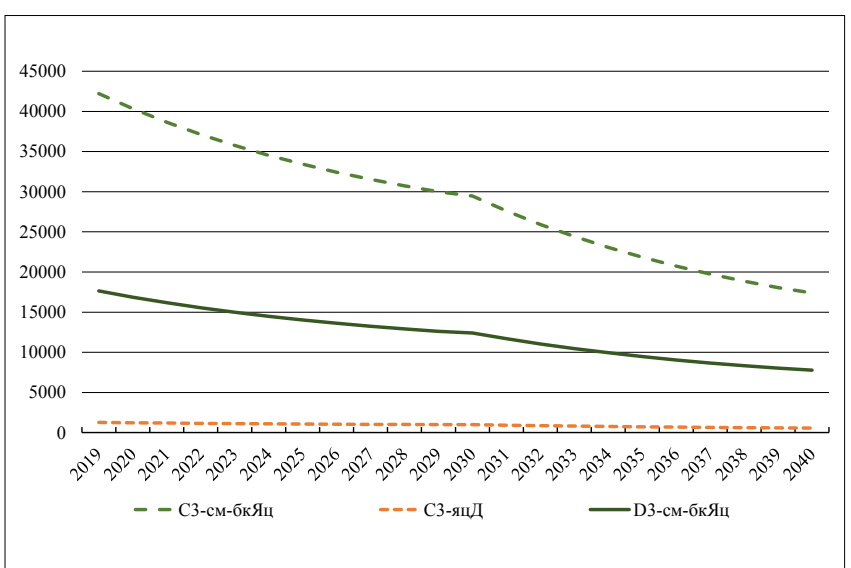

Рис. 5. Динаміка площі (га) ялинників в ялицевих типах лісу

Запас деревини ялинників в ялицевих типах лісу, порівняно зі смерековими типами лісу, змінюється плавно, однак швидкість зменшення запасів значно вища, ніж зменшення площі ялинників, в межах одного і того самого типу лісу (рис. 6). Так, в умовах вологої смереково-букової суяличини запас деревини ялинників зменшився на 81 \% (площа - на $55 \%$ ), для вологої ялицевої судіброви це зменшення склало 89, а для вологої смереково-букової яличини $71 \%$. Тобто, втрати ялинової деревини в ялицевих типах лісу Українських Карпат у найближчі 20 років прогнозуються в межах 71-89\% від існуючого запасу за середнього значення в $80 \%$, що навіть менше, порівняно зі смерековими типами лісу (рис. 7).

Сумарно за всіма типами лісу Українських Карпат прогноз вказує на зменшення площі ялинників внаслідок їхнього всихання на 96,7 тис. га (на 23\%) вже в найближчі 20 років, тобто площа ялинників на підприємствах Державного агентства лісових ресурсів України в регіоні складе 328,9 тис. га в 2040 році.

Запас ялинової деревини теж має стійку тенденцію до зменшення, яке до 2040 р. складе 113,5 млн м ${ }^{3}$ або $78 \%$ (рис. 8). При цьому, інтенсивність зменшення запасу деревини ялини значно вища за відповідне зменшення площі ялинників (78 проти $23 \%$ ), що пояснюється масовим всихання ялини в чистих деревостанах і перетворенням чистих ялинників на мішані деревостани природним шляхом (поява природного поновлення бука, ялиці, берези, в'яза на місці ялини, що всохла).

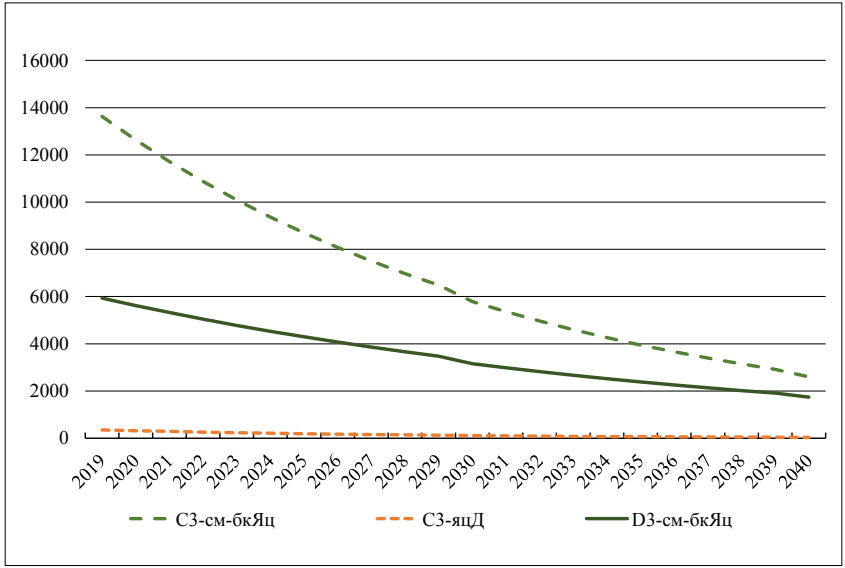

Рис. 6. Динаміка запасу деревини (тис. м³) ялинників в ялицевих типах лісу

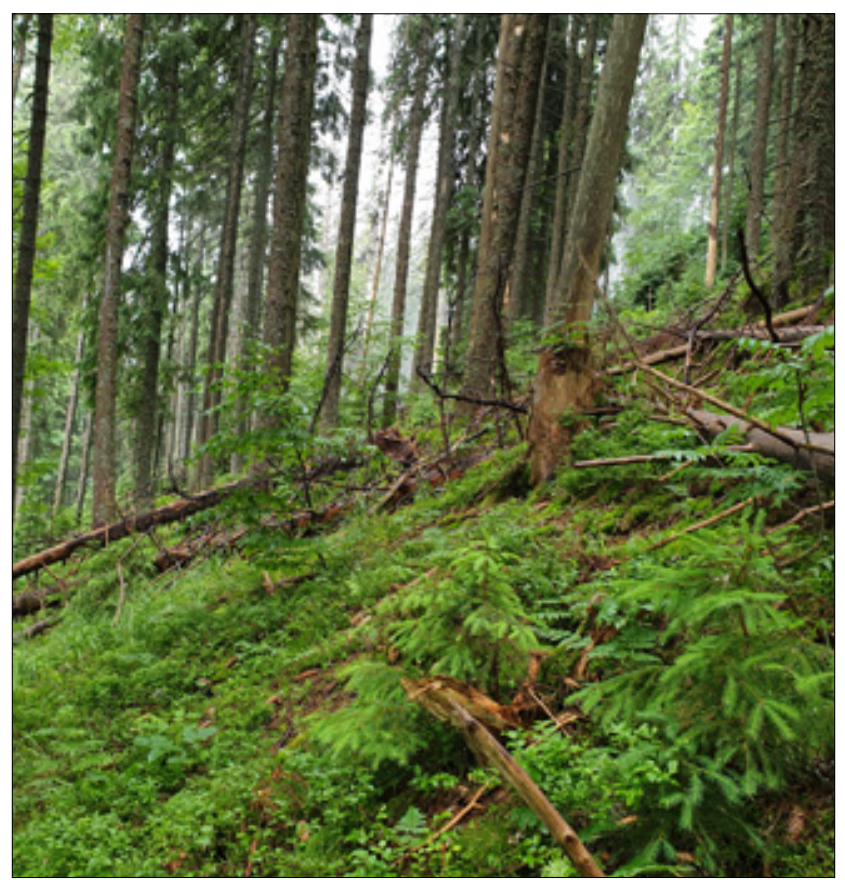

Рис. 7. Фрагмент середньовікового похідного ялинового насадження в умовах $C_{3}$-см-бкЯи Людвиківського л-ва ДП «Вигодське ЛГ»

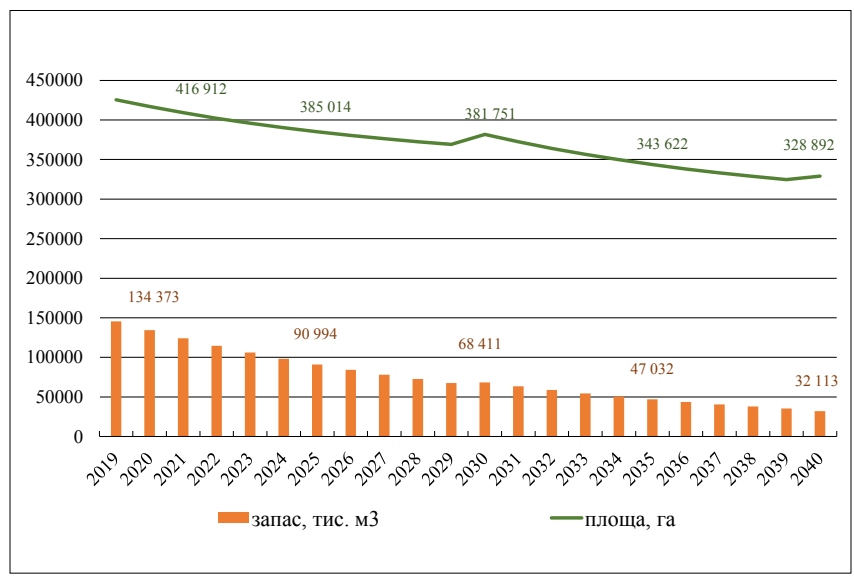

Рис. 8. Прогнозована динаміка всихання ялинників в Українських Карпатах на підприємствах ДАЛРУ 
Зрозуміло, що для окремо взятого підприємства лісового господарства Карпатського регіону прогноз всихання ялини матиме свої конкретні значення як за площею, так і за запасом, тому що критерії прогнозування лісового фонду ялинників (типи лісу, групи віку, повнота деревостанів, частка ялини у породному складі) в межах кожного підприємства індивідуальні. Зокрема, цей метод апробовано для прогнозу площі і запасу ялинників для ДП «Надвірнянське лісове господарство» в умовах найбільш поширеного типу лісу - вологої буково-ялицевої сусмеречини. Отримані результати також підтверджують різке зменшення запасів ялинників унаслідок всихання - впродовж 20 років прогнозується зменшення запасів ялинової дере-

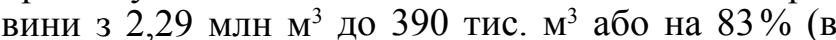
середньому для цього типу лісу в регіоні прогнозується зменшення запасу стовбурової деревини на $77 \%$ ). Площа ялинників при цьому зменшиться не так сильно - $з$ 6,5 до 5,3 тис. га або на $19 \%$ (в середньому для регіону - на $9 \%$ ).

Висновки. Ідентифіковані на постійних дослідних об'єктах УкрНДІгірліс зміни в структурі та породному складі всихаючих ялинників Українських Карпат впродовж 2010-2018 рр. дали можливість оцінити інтенсивність їх всихання, зокрема-відносну частку зменшення запасу стовбурової деревини живих дерев смереки за типами лісу. Так, для вологої чистої сусмеречини середня інтенсивність всихання склала $3 \%$ в рік, для вологої буково-ялицевої сусмеречини - $1 \%$, а для вологої смереково-букової суяличини - $2 \%$ за рік. Також встановлено закономірності всихання Picea abies за типами лісу: за збільшення вологості повітря і грунту інтенсивність всихання ялини зменшується, а за зменшення вологості - збільшується; за збільшення родючості інтенсивність всихання ялини зменшується, а за зменшення родючості - збільшується. В мішаних деревостанах букових, ялицевих та смерекових типів лісу інтенсивність всихання ялини менша, ніж у чистих. У букових та ялицевих типах лісу інтенсивність всихання ялини більша, ніж у смерекових, а в типах лісу поза межами природного ареалу ялини інтенсивність всихання ще вища.

Оскільки катастрофічне всихання ялинників Карпатського регіону вже у найближчі десятиріччя призведе до дефіциту ялинової деревини, то прогнозування площі ялинників і запасів ялинової деревини $€$ однією із найактуальніших наукових проблем для підприємств лісового господарства Українських Карпат. Здійснені дослідження дали змогу ідентифікувати основні складові ялинових лісів (критерії прогнозування), які найбільшою мірою впливають на результати прогнозу щодо всихання ялинників: тип лісу (визначає інтенсивність всихання ялини, оскільки представляе конкретний тип лісорослинних умов, а також відображає зміни в ньому по гігротопу і трофотопу); група віку насаджень (визначає життєздатність ялинників, яка зменшується з віком); повнота деревостану (визначає мікроклімат в лісі, який стає сухішим у випадку розрідження деревостану - зменшенні повноти); частка ялини у породному складі (впливає на інтенсивність всихання ялинників, оскільки всихання інших деревних порід $€$ помітно слабшим).

Відповідно до визначеної на постійних дослідних об'єктах інтенсивності всихання ялини, розроблено макет прогнозування, який базується на розподілі площ і запасів ялини за критеріями прогнозування з використанням відповідних даних лісовпорядкування. Результати прогнозу свідчать, що втрати ялинової деревини в смерекових типах лісу Українських Карпат у найближчі 20 років будуть коливатися в межах 48-95\% залежно від лісорослинних умов, віку, повноти і частки ялини в породному складі деревостанів; середні втрати складуть близько $80 \%$. Значний розмах коливань пояснюється високою мінливістю лісорослинних умов у смерекових типах лісу - від $A_{3}-\kappa C м$ до $C_{4}-б \kappa-я щ C м$. Для букових типів лісу ці коливання щодо втрати деревини складуть 77-97\% (середні втрати - 92\%), а для ялицевих - відповідно, 71-89 та 80\%. Інтенсивність всихання ялини у смерекових та ялицевих типах лісу відносно подібна і $€$ меншою, ніж для букових типів лісу.

Середні втрати площі ялинників значно менші, ніж втрати у запасі деревини: в смерекових типах лісу -28 , в букових -63 , в ялицевих $-53 \%$ до 2040 року. Відзначимо, що інтенсивність втрати площі ялинників близька для букових і ялицевих типів лісу, тоді як для смерекових вона значно менша. Тобто, під час всихання похідних ялинників має місце зміна головної породи, а при всиханні корінної породи площа ялинників не зменшується.

У підсумку зазначимо, що всихання ялинників Українських Карпат в наступні 20 років буде суттєвим для всіх державних підприємств лісового господарства і наслідком цього стане зменшення площі ялинників 3425,6 до 328,9 тис. га, а запасу ялинової деревини - 3 145,6 до 32,1 млн м³. Втрати окремих підприємств залежать від переважаючих у держлісфонді типів лісу, груп віку ялинників, повноти і частки ялини в породному складі смерекових лісів.

\section{References}

Bergha, J., McMurtrieb, R.E., \& Linder, S. (1998) Climatic factors controlling the productivity of Norway spruce: A model-based analysis. Forest Ecology and Management, 110 (1-3), 127-139. Available at: https://www.academia.edu/20503188/ Climatic_factors_controlling_the productivity_of Norway spruce $\overline{\mathrm{A}}$ model-based analysis

Bigun, N.Y. (1990). Spruce forests of the beech zone in the Carpathians. Uzhgorod: Karpaty (in Russian). Bokoch, V.V., Lakyda P.I., Vasylyshyn, A.I., Terentjev, A.Y. (2012). Modeling of the phytomass components indicators for forest stands of the Carpathian NPP. Scientific bulletin of the National 
Agrological University: Forestry, 171.2, 18-25 (in Ukrainian).

Debryniuk, Iu. M. (2011). Dieback of the spruce forests: causes and consequences. Scientific bulletin of the Ukrainian State Forestry University, 21.16, 32-38. http://nltu.edu.ua/nv/Archive/2011/21_16/ index 21 16.htm (in Ukrainian).

Debryniuk, Iu. M. (2014). Formative variety and Life condition Picea abies [L.] Karst. in the Western Forest-steppe of Ukraine. Journal of Agrobiology and Ecology, 4 (1), 97-102 (in Ukrainian).

Dunn, A.L., Barford, C.C., Wofsy, S.C., Goulden, M.L., \& Daube, B. C. (2006). A long-term record of carbon exchange in a boreal black spruce forest: means, responses to interannual variability, and decadal trends. Global Change Biology, Retrieved from http://onlinelibrary.wiley.com/ doi/10.1111/j.1365-2486.2006.01221.x/full

FAO (2016). Global forest resources assessment 2015. How are the world's forests changing? Second edition. Rome, FAO. Available at: http://www.fao. org/3/a-i4793e.pdf.

Feltona, A., Lindbladh, M., Bruneta, J., \& Fritz, Ö. (2010). Replacing coniferous monocultures with mixed-species production stands: An assessment of the potential benefits for forest biodiversity in northern Europe. Forest Ecology and Management, 260 (6), 939-947. https://doi.org/10.1016/j. foreco.2010.06.011

Fenton, N. J., Simard, M., \& Bergeron, Y. (2009). Emulating natural disturbances: the role of Silviculture in creating even-aged and complex structures in the black spruce boreal forest of eastern North America. Journal of Forest Research, 14, 5, 258-267. https://doi.org/10.1007/s10310-009-0134-8

Gerushinskyy, Z. Yu. (1996). Typology of Ukrainian Carpathian forests. Lviv: Pyramid

Golubets, M.A. (1978). Spruce forests of the Ukrainian Carpathians. Kyiv: Naukova dumka (in Russian).

Janda, P., Svoboda, M., Bače, R., Čada, V., Lynn, J., $\&$ Peck, E. (2014). Three hundred years of spatiotemporal development in a primary mountain Norway spruce stand in the Bohemian Forest, central Europe. Forest Ecology and Management, 330 (15), 304-311. https://doi.org/10.1016/j.foreco.2014.06.041

Kansanen, K, Vauhkonen J., Lähivaara T., \& Mehtätalo L. (2016). Stand density estimators based on individual tree detection and stochastic geometry. Canadian Journal of Forest Research, 46 (11), 13591366. https://doi.org/10.1139/cjfr-2016-0181.

Kirschbaum, M.U.F. (2004). Direct and indirect climate change effects on photosynthesis and transpiration. Plant Biology, 6 (3), 242-253. https:// doi.org/10.1055/s-2004-820883

Kramarets, V. O., Matsyak I.P. (2018). The role of biotic factors in the spruce forests decline of the Ukrainian Carpathians. Scientific works of the Ukrainian Forestry Academy of Sciences, 17, 121-132. https:// doi.org/10.15421/411827 (in Ukrainian).
Lakyda, P.I., \& Blyschyk, V.I. (2014). Forecast of carbon stock and oxygen production of alder forest in Ukrainian Polissya. Bioresources and nature management, 6, (1-2), 91-98 (in Ukrainian).

Lavryk, V.I. (2010). Modeling and forecasting of the environment. Kyiv: Scientific thought (in Ukrainian).

Mauer, O., \& Palátová, E. (2010). Decline of Norway spruce in the Krkonoše Mts. Journal of Forest Science, 56 (8), 361-372. https://doi.org/10.17221/95/ 2009-JFS

SAFRU (2019). Assortment structure of main use felling in 2020 for State Agency for Forestry Resources of Ukraine. Retrieved from https://drive. google. com/file/d/11YmR8HqKJKPQYs_U6HVOX 6jJNa-0VnHc/view

Šebeň, V., Konôpka, B., Bošel'a1, M., \& Pajtík, J. (2015). Contrasting development of declining and living larch-spruce stands after a disturbance event: a case study from the High Tatra Mts. Forestry Jornal, 61 (3), 157-166. https://doi.org/10.1515/forj2015-0024

Shparyk, Y.S. (2014). Form diversity and health conditions of Norway spruce (Picea abies (L.) Karst.) in the main forest types of the Ukrainian Carpathians. Forestry \& Forest Melioration, 125, 87-96. http://www.irbis-nbuv.gov.ua/cgi-bin/irbis nbuv/cgiirbis_64.exe?I21DBN=LINK\&P21DBN= UJRN\&Z2 $1 \mathrm{I} \overline{\mathrm{D}}=\& \mathrm{~S} 21 \mathrm{REF}=10 \& \mathrm{~S} 21 \mathrm{CNR}=20 \& \mathrm{~S} 2$ $1 \mathrm{STN}=1 \& \mathrm{~S} 21 \mathrm{FMT}=\mathrm{ASP}$ meta $\& \mathrm{C} 21 \mathrm{COM}=\mathrm{S} \& 2$ $\mathrm{S} 21 \mathrm{P} 03=\mathrm{FILA}=\& 2 \_\mathrm{S} 21 \mathrm{STR}=$ lisam_2014_125_14 (in Ukrainian).

Shparyk, Y. S.(2017).Economic results of spruce forests' decline in the Ukrainian Carpathians. Proceedings of the Forestry Academy of Science of Ukraine, 15, 129-139. https://doi.org/10.15421/411717 (in Ukrainian).

Shparyk, Y.S. (2019a). Ecologic results of spruce forests' decline in the main forest types of the Ukrainian Carpathians. Proceedings of the Forestry Academy of Science of Ukraine, 18, 145-153. https:// doi.org/10.15421/411915 (in Ukrainian).

Shparyk, Y.S. (2019b). Empirical approaches to forecasting area and wood volume of spruce (Picea abies (L.) Karst.) forests in the Ukrainian Carpathians. Scientific bulletin of the UNFU, 29.3, 18-22. https:// doi.org/10.15421/40290303 (in Ukrainian).

Shparyk, Y.S., Parpan, T. V., Slobodyan, P.Y., Savchyn, T.I., \& Bunij, V.Y. (2013). Spruce forest decline on the north-eastern megaslope of the Ukrainian Carpathians. Scientific bulletin of the Ukrainian National Forestry University, 23.5, 141147. https://nv.nltu.edu.ua/Archive/2013/23_5/141_ Szp.pdf (in Ukrainian).

Slobodyan, P. Ya. (2000). Areas of the spruce forest decline of Skole Beskids in different forest types. Scientific bulletin of the Ukrainian State Forestry University, 10.4, 182-184. https://nv.nltu.edu.ua/ Archive/2000/10 4/index.htm (in Ukrainian). 
Trybun, P.A. (1996). Bioecological basis of forest plantations cultivation with resistant to fungal diseases in the Ukrainian Carpathians. Scientific bulletin: Forestry Research in Ukraine, 5, 72-76 (in Ukrainian).

UkrRIMF (2014). Studying of Spruce forests decline reasons in the Carpathian region for the forestry instruction preparation on the management plane for these forests and on the forestry actions for their transformation on native stands. Final report. IvanoFrankivs'k, UkrRIMF (in Ukrainian).

Vasechko, G. I. (1967) Bark beetles and their control in the spruce forests of the Carpathians. Doctoral dissertation, Ukrainian Agricultural Academy, Kyiv, Ukraine (in Russian).

\section{Прогноз усыхания ельников в Украинских Карпатах по типам леса}

\author{
Ю.С. Шпарык ${ }^{1}$
}

Наиболее отрицательным последствием массового усыхания ельников Украинских Карпат является потеря большей части еловой древесины, которая практически безальтернативна для многих отраслей производства. Прогноз усыхания даст возможность предприятиям лесного хозяйства своевременно принять соответствующие меры. Исследования интенсивности усыхания ельников проведены в 2010-2019 гг. на 21-ом стационарном объекте в основных типах леса региона. Методика исследований предусматривала оценку запасов древесины Picea abies в разрезе категорий санитарного состояния деревьев этого древесного вида. Полученные результаты позволили идентифицировать зависимости интенсивности усыхания ельников от тех составляющих, которые собственно и являются определяющими для роста ели: тип леса, группа возраста, полнота, участие ели в породном составе. Для типов леса, в которых произрастают еловые древостои, установлены следующие закономерности: при увеличении влажности интенсивность усыхания ели уменьшается, а при её уменьшении - увеличивается; при увеличении плодородия почвы интенсивность усыхания ели уменьшается, а при его уменьшении - увеличивается; в смешанных насаждениях интенсивность усыхания $P$. abies меньше, чем в чистых (однопородных); в пихтовых и буковых типах леса интенсивность усыхания ели больше, чем в еловых. В типах леса за пределами естественного ареала интенсивность усыхания ели наиболее высокая.

В соответствии с установленными интенсивностью и закономерностями усыхания $P$. abies, была разработана схема прогнозирования, которая базируется на распределении площади и запасов ели по критериям прогнозирования и рассчитана с использованием данных лесоустройства. По результатам прогноза, потери еловой древесины в еловых типах леса Украинских Карпат в ближайшие 20 лет будут колебаться в пределах 48-95\% в зависимости от лесорастительных условий, возраста насаждений, полноты и участия ели в породном составе древостоев; средние потери составят около $80 \%$. Значительный размах колебаний объясняется высокой изменчивостью лесорастительных условий в еловых типах леса региона - от влажного бора $\left(A_{3}\right)$ до сырого груда $\left(D_{4}\right)$. Для буковых типов леса эти колебания составят в пределах 77-97\% при средних потерях в $92 \%$; для пихтовых типов леса, соответственно, 71-89 и 80\%. Лесоводственную достоверность полученных результатов подтверждает тот факт, что интенсивность усыхания ели в еловых и пихтовых типах леса довольно похожая и меньше, чем для буковых типов леса.

По сравнению с запасами древесины, средние потери площади ельников значительно меньше: в еловых типах леса не больше $28 \%$ к 2040 году, в буковых -63 , в пихтовых - $53 \%$. Отметим, что интенсивность потери площади ельников довольно близка для буковых и пихтовых типов леса, тогда как для еловых она значительно меньше, поскольку при усыхании производных ельников имеет место замена главной породы, а при усыхании коренных насаждений такая замена не происходит.

Общий вывод заключается в том, что усыхание ельников Украинских Карпат в следующие 20 лет будет существенным вызовом для государственных предприятий лесного хозяйства и его следствием станет уменьшение площади ельников с 425,6 до 328,9 тыс. га, а запаса еловой древесины - с 145,6 до 32,1 млн м². Конкретные потери отдельных предприятий будут зависеть от типов леса, возраста насаждений, полноты и участия ели в породном составе. Представленные расчеты подтверждают необходимость разработки региональных программ по восстановлению еловых лесов в Украинских Карпатах.

Ключевые слова: площадь ельников; запас еловой древесины; интенсивность усыхания; лесорастительные условия; группы возраста; полнота; состав пород; экстраполяция; государственные предприятия лесного хозяйства.

Шпарык Юрий Степанович - член-корреспондент Лесной академии наук Украины, доктор сельскохозяйственных наук, главный научный сотрудник. Украинский научноисследовательский институт горного лесоводства имени П.С. Пастернака, ул. Грушевского, 31, г. Ивано-Франковск, 76018, Украина. Тел.: 0342-53-02-36, +38-050-188-02-61. E-mail: yuriy.shparyk@gmail.com ORCID: https://orcid.org/ 0000-0001-8047-6356 


\section{Forecast of the Norway spruce forests' decline at the Ukrainian Carpathians according to forest types}

\author{
Y. Shparyk ${ }^{1}$
}

The most negative result of the mass decline of the spruce forests in the Ukrainian Carpathians is the loss of most of the spruce wood stock, which is practically uncontested for many industries. The decline forecast gives a chance for forestry enterprises to respond appropriately in good time. The studies of the decline intensity of the Norway spruce stands were in 20102019 at 21 stationary objects in the main forest types of the region. The research methodology provided for the assessment of spruce wood stock in the context of health conditions of this tree species. The results made it possible to identify the interrelations of the decline intensity of spruce forests according to the stand indicators that mainly determine its: forest type, age groups, basal area, and species composition. For example, the next interrelations have been established for forest types: with increasing of the forest types humidity, decline intensity of spruce forests decreases, and with humidity decreasing, intensity increases; with increasing of the forest types fertility, decline intensity of spruce forests decreases, and with fertility decreasing, intensity increases; in mixed forest types, decline intensity of spruce forests is less than in pure (one species) forest types; in non-spruce forest types, decline intensity of spruce forests is higher than in spruce ones; and in forest types outside the spruce areal it is even higher.

In accordance with the established intensity and trends of the spruce forests decline, a forecast scheme

Yuriy Shparyk - Corresponding Member of the Forestry Academy of Sciences of Ukraine, Doctor of Agricultural Sciences, Chief Scientist of the Ukrainian Research Institute for Mountain Forestry after P. S. Pasternak, Grushevsky str., 31, Ivano-Frankivsk, 76018, Ukraine. Tel.: 0342-53-02-36, + 38-050-188-02-61. E-mail: yuriy.shparyk@gmail.com ORCID: https://orcid.org/0000-00018047-6356 was developed, which is based on the distribution of the area and wood stock of the Norway spruce according to the forecast's criteria and calculated according to forest inventory data. Results of the forecast indicate that the loss of spruce wood volume in the spruce forest types of the Ukrainian Carpathians in the next 20 years will fluctuate from 48 to 95 percent depending on site conditions, age, basal area, and proportion of spruce in the species composition of stands, and the average loss will be $80 \%$. A significant fluctuation of these percent is explained by the high variability of site conditions in the regional spruce forest types from wet suboligotrophic to raw megatrophic. For Common beech forest types, these fluctuations will be from 77 to 97 percent and average losses $-92 \%$, and for Silver fir forest types - suitably 71-89 and 80\%. Decline intensity of spruce forests in the spruce and fir forest types is the same and less than for beech forest types, and that confirm forestry correctness of the prediction results. The average losses in the area of spruce forests are smaller than spruce wood volume: in spruce forest types -28 percent to 2040 , in beech 63 , in fir $-53 \%$. Note, that the loss of spruce forests area is closer for beech and fir forest types than for spruce ones, where for it is much less. It is because when the secondary spruce stands decline - the main species changes (for example, from Norway spruce on Common beech), but when the native spruce stands decline - it is not.

The spruce forests' decline in the Ukrainian Carpathians in the next 20 years will be significant for state forestry enterprises and its result will be decreasing in the area of spruce forests from 425.6 to 328.9 thousand hectares, and of the spruce wood volume - from 145.6 to 32.1 million $\mathrm{m}^{3}$. The individual enterprises' losses depend on the forest types, age, basal area and the spruce part in the species composition of their spruce forest. These predictions confirm a necessity to develop a regional program for the spruce forests restoration in the Ukrainian Carpathians.

Key words: spruce forest area; wood stock of spruce; decline intensity; site conditions; age groups; basal area; tree species composition; extrapolation; state forestry enterprises. 